\title{
Hic sunt dracones? Mapping the Legal Framework of China's Innovation Policy: Standardization and IPRs
}

\author{
Piergiuseppe Pusceddu
}

Published online: 9 June 2020

(C) The Author(s) 2020

\begin{abstract}
China's economy has been growing at a rapid rate over the past 30 years. Initially, economic development was pursued through leveraging the supply of cheap labour for export purposes. After China joined the World Trade Organization, the Chinese government realized the importance of cultivating innovation capabilities. As such, Chinese policymakers formulated what is known as an "indigenous innovation" policy, emphasizing the importance of Chinese-owned technology, standards, and intellectual property rights (IPRs). Academic scholars have studied China's innovation policy from different disciplinary angles, in particular from the perspective of its political economy. Important contributions have analyzed the connections between China's standardization regime and its IPR regime - especially in the area of information and communications technology. Although these contributions provide a valuable account of the dynamics within the regime(s), this phenomenon has not been analyzed from a legal perspective. This article aims to fill this gap by tracking the evolution of the legal framework of China's innovation policy since the 1950s, including recent developments. More specifically, it seeks to
\end{abstract}

\footnotetext{
This article is based on a presentation given at the first IP and Innovation Researchers Asia (IPIRA) Conference, Kuala Lumpur, 31 January-1 February 2019, and on a presentation given at the China-EU School of Law PhD workshop on recent developments in Chinese Law, University of Hamburg, 24 May 2019. The research on which this article is based was conducted in accordance with the rules set out in the Royal Dutch Academy of Sciences (KNAW) Declaration of Scientific Independence. Any errors or misconceptions are the author's alone.
}

Piergiuseppe Pusceddu is a PhD Candidate at the University of Tilburg in the Netherlands. He is a Qualified Attorney in Italy. He has an LL.M. from the National University of Singapore, an LL.M. from the New York University School of Law, and a Laurea in Giurisprudenza from the University of Cagliari.

P. Pusceddu ( $\square)$

PhD Candidate, University of Tilburg, Tilburg Law and Economics Center (TILEC), Tilburg, The Netherlands

e-mail: piergiuseppe.pusceddu@gmail.com 
determine how China's innovation policy has resulted in the development and adoption of laws, rules, and regulations regarding standardization and IPRs with the aim of realizing China's innovative potential and economic prosperity.

Keywords China - Indigenous innovation · IT · IPRs · National innovation · Standardization

Leges humanae nascuntur, vivunt, et moriuntur.

It's only those who do nothing that make no mistakes, I suppose.

- J. Conrad, An Outcast of the Islands.

\section{Introduction: China, National Innovation, Standardization and IPRs}

Technology standards are now more important than ever, and latecomers to standardization such as China have sparked both interest and concern in the international trade community.

Technology standards - defined as "agreed-upon technology platforms for interconnection, operation, or function on which other applications, improvements, and innovations can be made" - are an important constituent of modern life. They are necessary for communication and data exchange via electronic devices and for the latter's interoperability. ${ }^{2}$ Such standards, and the related intellectual property rights (IPRs), acquire significant value when they become crucial to manufacturing a product. Moreover, standard-essential patent (SEP) holders can determine the future trends of standardized technologies as a standard "freezes" a certain technology, making the development of alternatives difficult. ${ }^{3}$

Standards fit into two main categories: (i) market-based or de facto and (ii) formal or de jure. De facto standards are the result of market competition. The development and administration of formal standards is the prerogative of standardsetting organizations (SSOs). Within SSOs, technical committees (TCs) develop standards in relation to a specific area of competence; groups of experts propose, test, debate, and adopt the standard through consensus and majority voting. IPRs are included in technology standards by way of a system of good faith disclosure of the patent that may be relevant or essential to the standard under discussion. ${ }^{4}$ Disclosure seeks to prevent standard implementers from breaching existing patents.

\footnotetext{
${ }^{1}$ Breznitz and Murphree (2011), p. 7, (2012a), p. 4. Murphree and Breznitz (2013), p. 201. Technology standards are part of the broader concept of a "standard", defined as "a published document which sets out technical specifications, guidelines or rules for common and repeated use in order to ensure quality, safety and interoperability of products", ISO/IEC Guide 2:2004 - Standardization and Related Activities, General Vocabulary.

2 Consider the example of the Universal Serial Bus (USB), which has become a global standard for interfacing personal computers with peripheral devices.

3 Murphree and Breznitz (2016), pp. 2-3.

4 Breznitz and Murphree (2012a), p. 8.
} 
After the standard has been finalized and it is clear which patents it will include, SSOs' IPR policies address the licensing aspects of the relevant technology. Four positions are commonly taken: ${ }^{5}$

1. (Fair) Reasonable and Non-Discriminatory terms, also referred to as (F)RAND. This licensing term compels the licensing of the relevant technology to any interested party for a "reasonable" royalty fee.

2. RAND-RF (royalty free). Similar to FRAND, but without the licensing fee.

3. Participation in the patent pool.

4. No licence.

Concern regarding China's technology standards and related IPR policies has gained momentum as a post-World Trade Organization (WTO) phenomenon and is contingent on its rapid economic development. ${ }^{6}$ Over the past 20 years, China's gross domestic product (GDP) has grown steadily, even when other major economies - notably Japan, the US, and the EU - experienced recessions during the financial crisis. ${ }^{7}$ This economic achievement resulted in a rapid shift in Chinese society, from an agrarian model to an industrialized and urbanized one. ${ }^{8}$ China quickly established itself as a producer and consumer of technology-related goods and services, ${ }^{9}$ and, with a population of 1.386 billion (2017), ${ }^{10}$ it is a highly profitable market for technology companies. China is currently the largest patent filer in high-technology ${ }^{11}$ and second only to the US in research and development $(\mathrm{R} \& \mathrm{D})$ expenditure. ${ }^{12}$

These achievements are the outcome of the implementation of a series of technology-oriented policies since the 2000s, and they have had remarkable effects: since 1990 (when its annual export of technology goods was negligible), China's technology exports have increased to an estimated $\$ 504$ billion in $2017 .^{13}$

China's economic success is in part related to the realization of the importance of innovation and technology to economic development. ${ }^{14}$ The development of technology standards and related IPRs have been at the core of Chinese national innovation policy and serve the purpose of strengthening both indigenous innovation $^{15}$ and global competitiveness. ${ }^{16}$ Needless to say, this policy has been received with criticism from foreign and third countries, the US in particular, sparking a lively debate over the conformity of China's policy to international trade rules.

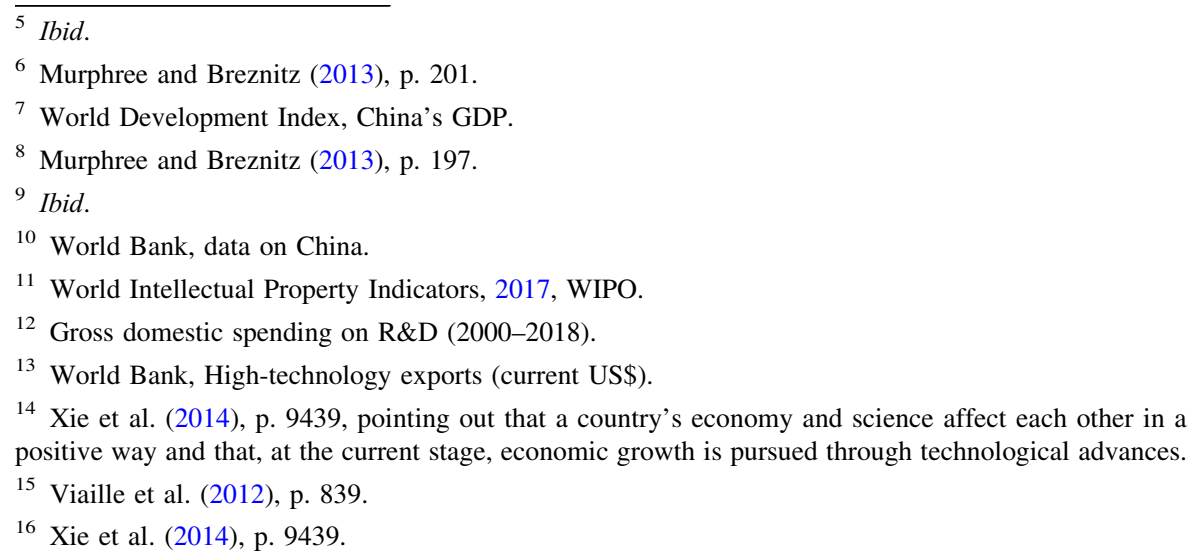


Against this backdrop, this paper contributes to the academic literature on innovation policy in China with regard to the legal framework of standardization and IPRs. The narrative has a holistic approach and addresses three questions: (i) How have the Chinese standardization and IPR regimes evolved since the 1950s? (ii) How has China's innovation policy affected these regimes, if at all? (iii) What factors (internal and external) explain the shift in China's innovation policy? The main thesis advanced in this paper is that China's innovation policy, especially from 1978 onwards, has been intended to allow China to catch up with the Western world. Standardization and IPRs have been essential to this process. Because of the economic conditions in China, however, policies related to IPRs in standardization have followed a different logic, which may cause friction with trading partners. The central aim of this paper is to (i) systematize a complex field of knowledge (ii) update it in light of recent legal developments, and (iii) develop a conceptual framework that can inform and stimulate debate on China's policy on innovation, standardization, and IPRs. This contribution is both timely and relevant given ongoing US-China tensions regarding technology and the importance of the Belt and Road project for the establishment of Chinese leadership in Asia and beyond.

\subsection{The Importance of Technology Standards for China}

The importance of technology standards and IPRs for China's economic development can be explained by a number of factors. First, China's innovation capabilities lie not in the creation of novel products but rather in incremental innovation, i.e. innovation that builds on existing inventions. ${ }^{17}$ This has been a source of concern for Chinese leaders. ${ }^{18}$ Since 1978, China has pursued the goal of becoming a wealthy country, ${ }^{19}$ maximizing its efforts in economic growth and innovation, and achieving consistent industrial development and R\&D expertise. Nevertheless, it has struggled to become truly innovative. This is especially the case in the ICT sector, which represents the greatest share of China's high-technology exports. Moreover, core technologies, which China relies on in the manufacturing of export products, are developed by foreign firms and protected by IPRs, which does not position China in the higher tier of the global value chain. ${ }^{20}$

Second, China's technology policy has played an important role in the promotion of its economic growth since the opening-up years, with the deployment of a series of programs focused on science and technology (ST). ${ }^{21}$ The Key Technologies Program (1982), the National High Technology Program (known as the "863 Program"), the Spark Program (1986) and the Torch Program (1988) were aimed at easing the commercialization of technology by means of establishing high-

\footnotetext{
17 Murphree and Breznitz (2013), p. 198.

18 Ibid. See Asian Scientist Magazine (2012).

19 Murphree and Breznitz (2013), p. 199. Ross (2012). Ross (2015). Baijie (2017). Omoruyi (2018).

20 Murphree and Breznitz (2013), p. 198. Breznitz and Murphree (2011), pp. 9-10.

21 Murphree and Breznitz (2013), p. 199. Springut et al. (2011), p. 24. Rongping and Wu (2005), pp. 910. Xie et al. (2014), p. 9439.
} 
technology zones and incubators. The "973 Program" (1998) was aimed at supporting basic research. Eventually, the projects carried on according to the Medium-Long Term Plan for Science and Technology. ${ }^{22}$ The common thread of these programs was to encourage the development of the technology sector and the commercialization of technological products developed in China. ${ }^{23}$ Initially, these programs were aimed at effecting a shift from manufacturing to indigenous innovation, that is, products designed, developed, and owned by Chinese firms; later, mainly after WTO accession, the focus shifted to the development of technology standards ${ }^{24}$ and related IPR policies.

Third, the approach to standardization taken by China and other latecomers is different from those adhered to by advanced economies, ${ }^{25}$ oriented more towards the success of standardization policy in terms of economic development, industrial upgrade, and global embeddedness rather than the economic success of standardization projects. Latecomers often try to shift from being standard implementers to being standard (co)shapers. This consideration should be kept in mind throughout this paper.

Technology standards have played a decisive role in China's technological emancipation. Emerging economies face difficulties in achieving technological and economic development independent of the use of foreign technologies. ${ }^{26}$ While benefiting from said technologies and producing according to international or advanced standards can initially foster development, this does not lead per se to technological upgrading or independent innovation. ${ }^{27}$ To this extent, governments may adopt measures aimed at attracting foreign talent (including overseas and domestic scientists), incentivizing education, sustaining $\mathrm{R} \& \mathrm{D}$, introducing tax advantages, and so forth. ${ }^{28}$ Additionally, the literature shows that access to foreign technology, coupled with the development of indigenous capabilities, leads to significant upgrading. ${ }^{29}$ In this regard, the development of technology standards is crucial. Developing standards involves the participation of several actors, including domestic and foreign firms, research institutes, and policymakers. ${ }^{30}$ It also requires understanding IPRs and mastering complex technologies. As such, standardization policies promote the development of indigenous capabilities, economic development, and technological upgrading ${ }^{31}$ as standards contribute to economic and productivity growth and the diffusion of knowledge. ${ }^{32}$

\footnotetext{
22 The Economist (2008).

23 Murphree and Breznitz (2013), p. 199.

24 Ibid.

25 Ibid. Wang et al. (2014), Ernst (2013).

26 Murphree and Breznitz (2018), p. 234.

27 Ibid.

28 Ibid. Xie et al. (2014), pp. 9437-9439.

29 Murphree and Breznitz (2018), p. 234.

30 Ibid., p. 235. Gao and Liu (2012). Kshetri et al. (2011).

31 Murphree and Breznitz (2018), p. 235.

32 Ernst et al. (2014), p. 854.
} 
The central role of the government in the design and execution of innovation policies ${ }^{33}$ has been described as an occurrence that is peculiar to China. ${ }^{34}$ There has been disagreement on whether China is really unique in this sense, ${ }^{35}$ however, as state intervention in the development of innovation policies is something that would seem to occur in many countries. Likewise, there is much debate on how the central role of the Chinese State in said policies has affected its technological processes. Some suggest that the strengthening of China's national innovation system will translate into a resurgent techno-nationalism, fostering the country's national interests to the detriment of other trade partners. ${ }^{36}$ On the other hand, the state's pervasiveness is viewed as hindering technological progress in the long run because it is associated with corruption and inefficiencies in the public sector and stateowned enterprises, ${ }^{37}$ which, coupled with a (perceived) discriminatory attitude against non-state companies (both foreign and domestic), impinges on the national innovation system. ${ }^{38}$ In approaching these views, one should bear in mind that the Chinese State is not a monolith with a unique vision and control over the economy. To the contrary, and as we will see below, the ongoing evolution of China's technology policies has been the result of a rethinking sparked both by dramatic transformations to the world production system and by domestic and foreign pressures.

\section{Science and Technology, Standardization and IPRs: From 1949 to the Cultural Revolution}

After its establishment in 1949, the economy of the People's Republic of China (PRC) was shaped in the form of a centrally planned economy. ${ }^{39}$ Its standardization regime was modelled after, and benefited from, that of the Soviet Union, with the government formulating plans and managing standardization activities nationwide. ${ }^{40}$

\footnotetext{
33 As far as the nomenclature is concerned, the term "national innovation system" is a Western creation, introduced in China in the 1990s. Before it, the main terminology used was "Science and Technology System" (ST), founded in the 1950s. Zhou and Liu, in: Zhou et al. (eds.) (2016), p. 34.

34 Ibid., p. 33.

35 Generally, Chang and Gershman (2003).

36 Generally, McGregor (2010).

37 Or will eventually lead to a situation similar to Japan's experience with "Galapagos Syndrome". Ezell and Atkinson (2014).

$38 \mathrm{Wu}$ and Huang (2008).

39 Ping et al. (2010), p. 2.

40 Ibid. Under the planned economy, the government took responsibility for initiating standard projects, organizing technical experts, and eventually preparing and publishing standards. Wang and Liang (2016), p. 3. Zhang and Yao (2006), p. 123. At p. 118, the authors point out that, as a result of the acceptance of Soviet product design and technology, China also adopted and incorporated Soviet technology and industrial standards.
} 
Cooperation with the Soviet Union laid the foundation for the Chinese ST system. ${ }^{41}$ This system was informed by the communist ideology, the geopolitics of the cold war, and years of conflict. It was characterized by a pronounced focus on the military and defence, a centralized and hierarchical bureaucracy, ${ }^{42}$ task-led $^{43}$ projects, and the indigenization of technology. In addition, this system allowed the PRC to make critical advances in heavy industries and the defence sector. ${ }^{44}$ In this economic setting, the purpose of standardization was to serve the planned economy, ${ }^{45}$ facilitate the government in organizing large-scale production, ${ }^{46}$ and make adequate and efficient use of resources. The system consisted of national, ministerial, local, and factory/enterprise standards. ${ }^{47}$

This progress was shaken by the Cultural Revolution (1966-1976) and the PRC's shift to an isolationist policy. While imported technologies from Japan, Germany, and the Soviet Union had previously been at the foundation of Chinese technology development, isolationism caused a foreign exchange shortage which, along with the Cold War tensions and the split from the Soviet Union, led to a cut in foreign aid. The cost of foreign technologies also increased steeply, which made the Chinese technology apparatus obsolete. ${ }^{48}$ This predicament boosted the role of Government Research Institutes (GRIs), which engaged in tracking international technological developments and replicating them: incremental innovation was reached through the reverse engineering of foreign technology, and intellectual property rights were not protected. ${ }^{49}$ The dominant approach to ST was thus an exacerbated version of techno-nationalism, which can be described as an unwillingness, on the part of the state, to open the domestic market to foreign direct investment on the grounds that foreign firms would stall the development of domestic ones. 50

Additionally, throughout this period, the allocation of research funding followed a top-down model, which in the long run worked to the detriment of China's competitiveness: although it was able to invest in resources for strategic tasks (e.g. defence), demonstrating the incredible technological and engineering talent and capacity of GRIs, it failed to plant the necessary seeds for participation in an international competitive environment, where innovation is sparked by players who, rather than acting according to a centralized, top-down vision, pursue their own individual gain. ${ }^{51}$

\footnotetext{
$\overline{41}$ Zhou and Liu, in: Zhou et al. (eds.) (2016), p. 34.

42 Suttmeier and Cao, in: Gu and Goldman (eds.) (2004), p. 139.

43 Zhou and Liu, in: Zhou et al. (eds.) (2016), p. 35.

44 Suttmeier and Cao, in: Gu and Goldman (eds.) (2004), p. 139.

45 Liu, in: Peng et al. (eds.) (2018a), p. 119. Rongping and Wu (2005), p. 2.

46 Liu, in: Peng et al. (eds.) (2018a), p. 119. Wang and Liang (2016), p. 3.

47 Ping et al. (2010), p. 2.

48 Zhou and Liu, in: Zhou et al. (eds.) (2016), p. 37.

49 Ibid.

50 Keller and Samuels (2003), p. 9.

51 Zhou and Liu, in: Zhou et al. (eds.) (2016), p. 37.
} 
2.1 From the Cultural Revolution to the Early 2000s (the Opening-up Period): ST Policies' Focus on the Civilian Sector

At the end of the Cultural Revolution, it was clear that the Chinese ST system had led to negligible advancements in domestic productivity and economic performance. ${ }^{52}$ Consequently, the end of the 1970 s marked a shift of focus in ST to the domestic economy. China opened up to foreign markets and goods, which had a significant impact on the role of GRIs. As China came to rely less on domestic products, the role of the Chinese State in the innovation system also decreased. ${ }^{53}$ As a consequence, GRIs and universities, now looking for alternative sources of income, established their own spin-off institutions to earn an income from the commercialization of their research. ${ }^{54}$ The marketization experiment undertaken by the GRIs (although important for the establishment of the first competitive and market-oriented Chinese tech enterprises ${ }^{55}$ ) did not last long, as in the late 1990s the government re-established the funding flow to research institutes.

The techno-nationalism that characterized the Cultural Revolution was set to gradually become obsolete as China took a progressive step into the global economy. This development facilitated an influx of foreign technology and foreign direct investment (FDI) into China, ${ }^{56}$ which in turn furthered China's technological transformation.

\subsubsection{Standardization}

The opening-up period had an impact on China's standardization and IPR regimes: ${ }^{57}$ the State General Bureau for Standardization was established in 1978, followed by the institution of the China Association for Standardization (1979). ${ }^{58}$ In 1978, China also re-joined the International Standardization Organization (ISO) and was elected as a member of its Council in 1982. ${ }^{59}$ The regulatory architecture for standards was also consistently reshaped, with the enactment of the "Administration Statute for National Standardization" in $1979^{60}$ and the "Administration Statute for Adopting International Standards" in $1982^{61}$ (trial) and $1984 .{ }^{62}$ These statutes

\footnotetext{
52 Suttmeier and Cao, in: Gu and Goldman (eds.) (2004), p. 139.

53 Zhou and Liu, in: Zhou et al. (eds.) (2016), p. 38.

54 That was the birth of the Chinese Silicon Valley.

55 Zhou and Liu, in: Zhou et al. (eds.) (2016), p. 39. Zhou (2005), pp. 1118-1120. Zhou (2008), pp. 2364-2365.

56 Wang and Liang (2016), p. 3.

57 Ping et al. (2010), p. 2. Liu, in: Peng et al. (eds.) (2018a), p. 119. Zhao and Graham (2006), p. 65.

58 Ping et al. (2010), p. 2.

59 Rongping and Wu (2005), p. 4.

60 The State Council, "Administration Statute for National Standardization”, 31 July (1979).

61 The State Economic and Trade Commission (now Ministry of Commerce), State Scientific and Technological Commission (now Ministry of Science and Technology) and Standardization Administration, "Administration Statute for Adopting International Standards (probation)", 17 March (1982).

62 Standardization Administration of China, "Administration Statute for Adopting International Standards", 27 March 1984, superseding the measures mentioned above.
} 
established three levels of standards: national, trade (previously called "ministry") and enterprise. ${ }^{63}$ Subsequently, the enactment of the Standardization Law (1988) 64 and the Regulation for Implementation of the Standardization Law (1990) ${ }^{65}$ was an attempt to make the standardization framework more consistent with the changing economic environment. The legal framework above refers to standardization in general and as such should be considered part of the legal framework assisting China's innovation policy.

The standardization law was enacted with the aim of improving product quality, developing the socialist commodity economy, promoting technical progress, and leveraging standardization in the development of economic relations with foreign countries. $^{66}$ The legislation therefore resonated with the role of the Chinese State in the economy and the development of ST policies in the period under analysis. Some provisions of the legislation are worth analyzing. Article 5 of the law provided that the department of the standardization administration - the General Administration of Quality Supervision, Inspection and Quarantine (AQSIQ) - under the aegis of the State Council was to oversee the administration of standards (in contrast to US practice, in which SSOs, such as ANSI, are treated as non-governmental organizations).

Article 6 provided for four groups of standards: (i) national standards, (ii) sector (trade) standards, (iii) local/regional standards, and (iv) enterprise standards. The first three types were linked to governmental input. ${ }^{67}$ The hierarchy among these standards was as follows: national standards were situated at the top and adopted for matters requiring consistency at the national level, ${ }^{68}$ trade standards were used in areas that were not covered by national standards but required harmonization; local standards played a role in matters not covered by national or trade standards; and finally, enterprise standards were situated at the bottom of the line and were set by companies to meet their needs, provided there was no applicable standard at the national, sectoral, or local level. ${ }^{69}$ Enterprise standards had to be reported to the standardization administration department and the competent administrative authorities under the local government for the purposes of keeping track of which standards had been applied.

Article 7 of the law divided standards into those that are compulsory and those that are voluntary. This provision has caused persistent misunderstanding, given that Western standardization systems and the WTO terminology distinguish between

\footnotetext{
${ }^{63}$ Snyder (2015), p. 188.

${ }^{64}$ Standardization Law of the People's Republic of China, Adopted at the Fifth Meeting of the Standing Committee of the Seventh National People's Congress on 29 December 1988 (1988 Standardization Law).

${ }^{65}$ Regulation for Implementation of the Standardization Law. Promulgated by Decree No. 53 of the State Council of the People's Republic of China on 6 April 1990 and effective as of the date of promulgation ("implementing regulation").

${ }^{66} 1988$ Standardization Law, Art. 1. The Standardization Law is clearly a piece of administrative legislation. See Burke (1987).

${ }^{67}$ Art. 6.

${ }^{68}$ Liu, in: Peng et al. (eds.) (2018a), p. 120. Zhao and Graham (2006), p. 67.

${ }^{69}$ Art. 6.
} 
technical regulations on the one hand and standards which are voluntary in nature on the other. Some clarification is necessary. In the Chinese classification, the code "GB" is used for mandatory national standards, while " $\mathrm{GB} / \mathrm{T}$ " is used for voluntary national standards; specific codes are used for industry/trade/sectoral standards, for instance: "YD" or "YD/T" for telecommunication standards; "DB + *" or "DB +*/T" are used for local government standards; and "Q" is used for enterprise standards. 70 As the Chinese terminology does not distinguish between standards and technical regulations, the absence of the suffix " $T$ " gives the standard its normative force by indicating that the standard is mandatory.

The law did not provide for a centralized review mechanism for standards; instead, the entity in charge of the formulation of the standard was to perform a timely review of the relevant standard. ${ }^{71}$

The law also did not set clear sanctions for non-compliance with standards. Absent prescriptions regarding non-compliance in law, administrative rules or regulations, the general remedy was the confiscation of the product and a monetary sanction; in extreme cases, non-compliance could constitute a criminal offence. ${ }^{72}$

Eventually, trade associations were given an embryonic role in standardization. Article 12 of the standardization law provided for the involvement of trade associations, scientific research institutions, and academic organizations in the formulation of standards, provided that a department engaged in the formulation of standards organized a standardization committee responsible for the drafting and examination of standards.

Although the Chinese standardization system remained greatly influenced by the planned economy period, ${ }^{73}$ certain aspects of the newly enacted standardization law aligned with, and were influenced by, more mature standardization regimes. ${ }^{74}$ These included in particular: (i) the division of standards into compulsory and voluntary, ${ }^{75}$ (ii) the creation of TCs for the development of standards, ${ }^{76}$ and (iii) the provision of an embryonic form of association standards. ${ }^{77}$

\footnotetext{
70 The English version of Chinese standards is available at: http://www.codeofchina.com.

71 Art. 13.

72 Art. 20.

73 Ping et al. (2010), p. 2.

74 Wang and Liang (2016), p. 3.

75 Art. 7: "[t]hose for safeguarding human health and ensuring the safety of the person and of property and those for compulsory execution as prescribed by the laws and administrative rules and regulations shall be compulsory standards, the others shall be voluntary standards".

76 Wang and Liang (2016), p. 3.

77 Hui and Cargill (2017), p. 15.
} 
2.1.1.1 China's Approach to International Standards Related to the discussion above is the question of whether China made any effort to align domestic standardization with its international counterpart. The enactment of the standardization law was followed in the early 1990s by regulations that implemented the standardization law. These regulations stressed the importance of including standardization in national plans for economic and social development ${ }^{78}$ and encouraged the adoption of international standards and advanced standards, as well as participation in international standardization activities. ${ }^{79}$ The regulations also added further details on the division of competences in the standardization work, ${ }^{80} \mathrm{a}$ hierarchy of standards, and sanctions for non-compliance. ${ }^{81}$

As regards the division of competences, the regulations delineated a clear picture of the standardization work. The competent authority under the State Council, which exercises general leadership over the standardization activity in China, is the AQSIQ. The Standardization Administration of China (SAC) is responsible for national standards; other departments (ministries) under the State Council are responsible for standardization according to their own areas of competence. The relation is somewhat intricate; not only is there a vertical level when it comes to the allocation of standardization activities (general supervision vs. responsibility for sectoral or sub-sectoral standards), but there is also a horizontal allocation of such activities among different departments.

In 1987, the State Council issued a report on the acceleration of the adoption of international standards, ${ }^{82}$ which stressed the importance of implementing international standards and advanced standards as a way to improve technological capability and product quality. At the end of 1993, the State Bureau of Technology Supervision embarked on the promotion of what has been described as a "dualadoption" policy on standardization. ${ }^{83}$ Concisely, this policy provided that the adoption of Chinese standards should be based on international standards (e.g. those issued by the ISO, the IEC, and the ITU), foreign advanced standards (e.g. those standards that have not been confirmed or published by the ISO), the national standards of developed countries, and the standards of regional organizations. The policy's basic tenet was that there was a consistent gap between China and other developed countries when it came to technical ability and competitiveness. ${ }^{84}$

\footnotetext{
$\overline{78 \text { Implementing Regulation, Art. } 3 .}$

79 Art. 4.

80 Arts. 5 to 10 .

81 Arts. 28 and 29.

82 General Office of the State Council: Report on Accelerating the Adoption of International Standards, 25 February (1987). Rongping and Wu (2005), p. 4.

83 Wang and Liang (2016), p. 3. State Bureau for Technical Supervision: Measures for the Administration of Adoption of International Standards and Advanced Foreign Standards, 13 December (1993), superseding the measures enacted in (1984), supra note 62.

${ }^{84}$ Wang and Liang (2016), p. 3, pointing out that this was part of a wider set of policies aimed at attracting FDI and foreign technology.
} 


\subsubsection{IPRs}

With the end of the Cultural Revolution, China renewed commercial and diplomatic relations with the US, Japan, and other developed countries. ${ }^{85}$ This led to the signing of an Agreement on Trade Relations with the US, which provided for the reciprocal protection of copyrights, patents, and trademarks ${ }^{86}$ and, in 1980, to China's becoming a member of the World Intellectual Property Organization (WIPO). ${ }^{87}$ New domestic laws on trademarks and patents were enacted in 1982 and 1984 (inspired by Western intellectual property laws), ${ }^{88}$ and China joined the Paris Convention in 1985. Despite these laws and China's accession to multilateral treaties, however, the general perception was that China was not providing sufficient protection to authors and inventors. Indeed, introducing concepts such as private property rights was not a priority for Chinese policymakers, as they were primarily concerned with the potential clashes that intellectual property rights, private and exclusive by definition, could generate within the Chinese economic system, in which socialism was deeply ingrained. ${ }^{89}$ As regards IPRs in particular, the Chinese legal system - sometimes referred to as "socialist legality with Chinese characteristics" - acknowledged the status of inventors and allowed them some form of material reward rather than monetization from authorship and inventions. ${ }^{90}$ Lack of IPR protection was a source of concern for American businesses, which began to lobby their home governments to put pressure on China to address the issue. The late 1980s and early 1990s was a period of tense relations between the US and China, with the former threatening economic wars, sanctions, and the vetoing of China's admission to the WTO. ${ }^{91}$ The outcome of this pressure was a Memorandum of Understanding (MoU) with China on the Protection of Intellectual Property in $1992,{ }^{92}$ the Agreement Regarding Intellectual Property Rights in $1995,{ }^{93}$ and an agreement reinstating China's commitment to IPR protection in $1996 .^{94}$

\footnotetext{
$85 \mathrm{Yu}$ (2004), p. 4.

86 Agreement on Trade Relations Between the United States of America and the People's Republic of China, 7 July 1979, U.S.-P.R.C., 31 U.S.T. 4652. Yu (2011b), p. 216.

87 As regards China's accession to WIPO, and accession status of the WIPO Convention, http://www. wipo.int/treaties/en/ShowResults.jsp?treaty_id=1.

${ }^{88} \mathrm{Yu}$ (2011b), p. 217. As to the dynamics of IPR transplants in China, Zhang and Bruun (2017).

89 Alford (1995), p. 70.

90 Ibid. Information Office, State Council of the People's Republic of China: Intellectual Property Protection in China (1994), which points out that "[a]fter China started reform and opening to the outside world, it accelerated the process of establishing an intellectual property rights protection system in order to rapidly develop social productive forces, promote overall social progress, meet the needs of developing a socialist market economy and expedite China's entry into the world economy". http://www.china.org. cn/e-white/intellectual/index.htm.

91 Yu (2000), pp. 140-51, which aptly describes the use of Sec. 301 and trade threats to induce China to protect intellectual property rights.

92 Memorandum of Understanding Between China (PRC) and the United States on the Protection of Intellectual Property, 17 January 1992, P.R.C.-U.S., 34 I.L.M. 677 (1995).

93 Agreement Regarding Intellectual Property Rights, 26 February 1995, P.R.C.-U.S., 34 I.L.M. 881 (1995).

94 Implementation of the 1995 Intellectual Property Rights Agreement, 17 June 1996, P.R.C.-U.S.
} 
Despite the above, IPR infringement remained a sensitive problem, and institutional reforms aimed at tackling the problem were pursued in the latter part of the 1990s. ${ }^{95}$ These reforms were combined with research programs in IPRs; likewise, universities introduced IP law into their curricula. ${ }^{96}$

\subsubsection{The Inadequacy of China's Policies}

Since the 1980s, China's economic policies were led by two goals: (i) the promotion of exports and (ii) import substitution. Export promotion policies were accompanied by tax policies, regulations, and infrastructural conditions to attract foreign direct investment in the special coastal economic zones ${ }^{97}$ and were overall successful in leveraging China's comparative advantage in providing cheap labour and attracting FDI from the US, the EU, Japan, and South Korea. While these policies boosted production capacity, it is questionable whether they contributed to enhancing technological innovation. ${ }^{98}$ Although there was a steady rise in Chinese exports of technology goods, and despite the outsourcing of upstream production by multinational firms, the value-added share generated by Chinese firms remained low, especially in high-tech sectors. ${ }^{99}$

Whereas the promotion of exports was successful, facilitating China's emergence as a key global exporter by 2009, import substitution policies, and in particular "trading market for technology" (TMFT) policies, were less successful. TMFT policies had an earlier start than export promotion: they were conceived between 1979 and 1981 and operationalized by $1984 .{ }^{100}$ The underlying idea was to induce the transfer of foreign technology from foreign enterprises to China in exchange for being allowed to sell a portion of their products in the Chinese market. ${ }^{101}$ The intuition was that exposing Chinese companies to production processes would allow

\footnotetext{
$95 \mathrm{Yu}$ (2004), p. 5, points out that, notwithstanding the abovementioned agreements, piracy remained a sensitive problem in China, with the US losing approx. \$2 billion in revenue annually in the late 1980s and early 1990s.

96 Yu (1994), p. 149.

97 Zhou and Liu, in: Zhou et al. (eds.) (2016), p. 40.

98 Ibid. Crookes (2012), p. 179.

$99 \mathrm{Xu}$ (2006). The author calculated that the percentage of products with technical content among total Chinese exports to the US increased by $19 \%$ from 1989 to 2001 . Wei and Wang (2012), pp. 1-3. They calculated that the aggregate domestic value-added share in China's merchandise exports was $54 \%$ in 1997 and $60.6 \%$ in 2007. However, they also found that the domestic value-added share is much lower in high-tech sectors, in the 30-40\% range. Along similar lines, a 2011 IMF report on global trade shows that the growth of China's high-tech exports is driven by the $99.4 \%$ growth of value added in foreign enterprises, which suggests that foreign enterprises are behind the technological upgrading of China's export industry and that China depends heavily on core technologies developed abroad. IMF (2011), p. 19. Xing (2014), p. 10.

100 Zhou and Liu, in: Zhou et al. (eds.) (2016), p. 40.

101 Ibid., which points out that China maintained strong protectionist policies at the time, prohibiting domestic sales of foreign products and allowing foreign direct investment (FDI) only for exports. In this context, TMFT projects were exempted from the abovementioned limitations. These projects were carried out through the creation of joint ventures between Chinese state-owned enterprises and foreign enterprises for producing in China, substituting direct imports. As a corollary, these joint ventures may have been eligible for preferential tax rates and special market access.
} 
them to absorb technology from foreign partners. ${ }^{102}$ These policies were later coupled with a progressive opening-up to the presence of fully owned foreign enterprises within Chinese territory and to the enactment of preferential industrial policies to stimulate MNC investment in particular sectors, such as energy, transportation, infrastructure, and high-tech. ${ }^{103}$ From their inception to the early 1990s, however, these policies were only able to attract labour-intensive production for export purposes and the final assembly stage of high-demand consumer electronics for the Chinese market. ${ }^{104}$

TMFT policies favoured a surge in the market share of foreign companies but failed to foster technology transfer. Foreign/Chinese joint ventures were based almost entirely on foreign-provided technology and were used as a pretext to acquire market access. ${ }^{105}$ Foreign partners also had little incentive to transfer technology: the promise of market access was independent of the continuous transfer of technology, and the disproportionate number of Chinese companies willing to enter into partnerships with foreign firms created an unbalanced situation in which the latter held more bargaining power. ${ }^{106}$

Additionally, Chinese companies put little effort into R\&D, assimilation and the improvement of technology processes. ${ }^{107}$ This can be explained by the fact that export promotion and TMFT policies sought to stimulate competitiveness and industrial upgrade, but on a mistaken premise. It was thought, in fact, that the mere embedding of technology in products and the localization of their production in China would naturally lead to the transfer of technology. ${ }^{108}$ This assumption was flawed, as it did not consider the global reorganization of the manufacturing industry, known as global production networks (GPNs), namely "the globally organized nexus of interconnected functions and operations by firms and non-firm institutions through which goods and services are produced and distributed". 109 The main way in which firms came to operate in a globalized market was through these networks. ${ }^{110}$ The position occupied by China in the GPN pyramid was the middle/ bottom area, ${ }^{111}$ with the consequence that Chinese firms could manufacture products without having a full grasp of the core know-how or technology. At the same time, not only the fragmentation of GPN production but also the uncertain interpretation and application of domestic policies by political and economic actors created incentives for Chinese companies to specialize in incremental, short-term

\footnotetext{
$\overline{102}$ Liu and Cheng (2014), p. 121.

103 Ibid.

104 Zhou and Liu, in: Zhou et al. (eds.) (2016), p. 41.

105 Ibid. Liu and Cheng (2014), pp. 121-122.

106 Ibid.

107 Zhou and Liu, in: Zhou et al. (eds.) (2016), p. 42.

108 Ibid.

109 Coe et al. (2004), p. 471.

${ }^{110}$ For an account of the GPNs and their dynamics, Ernst and Kim (2002), p. 1419.

111 Fischer (2010), pp. 755-756.
} 
innovation, to be risk-averse, and to avoid long-term R\&D projects (which are essential to fostering technological innovation). ${ }^{112}$

The situation can be summarized as follows: while foreign firms retained high margins of profit, keeping R\&D and the production of core technology in their home countries, Chinese companies specialized in assembly production based on imported core technologies, with (sometimes) lower profit margins. ${ }^{113}$ Consequently, it was necessary for China to develop innovation and to stop relying on the supply of cheap labour. The role of the state was thus crucial in steering the economy towards a technology-driven model, taking as an example the experiences of the US, Europe, Japan and South Korea during their "catch-up" processes. ${ }^{114}$ The above facts have shaped China's policies on standardization and IPRs in the post-WTO period.

With China's accession to the WTO, three further events should be added to this narrative. The first two are the agreements on WTO accession that China signed with the US and the EU, which stressed its commitment to removing barriers to trade, including standards. These accession protocols also required China to phase out performance requirement assessments in domestic/foreign joint ventures, as well as any form of (forced) technology transfer. ${ }^{115}$ This fact reinforces the importance of standardization as a way to legitimately effect the transfer of technology in the technology process. The third connected development was the General Administration of Quality Supervision, Inspection and Quarantine (AQSIQ)'s adoption (in 2001) of a new set of measures that superseded those enacted in 1993 . $^{116}$ The turning point of these measures is that they refer to the relevant provisions of the WTO and the ISO. ${ }^{117}$ In particular, their aim was to set a general policy as regards alignment with international standards, to clarify the relationship between domestic and international standards, to circumstantiate what is involved in the "adoption" of international standards, ${ }^{118}$ and to clarify what is meant by "international standard". ${ }^{119}$ The measures signified a change in the government's view of standardization. While the government had seemed to be enthusiastic about learning from international standards in 1993, in 2001 the focus shifted to reasonably (and rationally) codifying national standards after learning from international ones. ${ }^{120}$

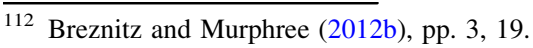

113 Zhou and Liu, in: Zhou et al. (eds.) (2016), p. 44.

114 On the role of the state in technology development generally: Block and Keller (2011); Mazzucato (2013).

115 Foreign-Sino technology transfer is a sensitive issue that depends on several factors. See Prud'homme et al. (2018).

116 The Administration of Quality Supervision, Inspection and Quarantine: Measures for the administration of adoption of international standards, 12 April (2001) (hereinafter referred to as "2001 measures").

1172001 measures, Art. 1.

118 Art. 2.

119 Art. 3. "International standards refer to standards established by the International Organization for Standardization (ISO), International Electrotechnical Commission (IEC), and International Telecommunication Union (ITU), as well as standards developed by other international organizations recognized and published by the International Organization for Standardization".
}

120 Snyder (2015), p. 197. 


\subsection{Post-WTO Accession: Innovation Policy}

The Chinese State began re-funding GRIs and universities in the mid-1990s, reversing the trend of the previous decade. This increased funding commitment became known to the public only in the 2000s, and in particular after 2006, the year China announced its "indigenous innovation" policy. ${ }^{121}$ This policy was embodied in the "National Programming 2006-2020 for the Development of Science and Technology in the Medium and Long Term" (MLP), ${ }^{122}$ often referred to as zizhuchuangxin (自主创新). The common translation, “indigenous innovation”, is misleading, however. The policy ${ }^{123}$ did not refer to technology that originated in China, to the exclusion of foreign contribution or participation. To the contrary, the term is better translated as "sovereign innovation", which unveils the ambition of controlling and improving national innovation capabilities through integrated innovation, re-innovation, and the assimilation/absorption of foreign technology. ${ }^{124}$ The policy was introduced to address the inefficacy of the TMFT policy by stimulating indigenous long-term $\mathrm{R} \& \mathrm{D}$ spending and by enticing domestic companies to engage strategically with foreign enterprises. ${ }^{125}$ Although the organization of some of the projects covered by the MLP maintained a top-down administration, its novelty lay in the fact that the MLP cultivated the involvement of enterprises and prioritized technology commercialization. ${ }^{126}$ Foreign technology and the creation of incremental innovation still played a prominent role in the MPL projects, ${ }^{127}$ while little attention was given to basic research. ${ }^{128}$ This is slowly changing, however. ${ }^{129}$

Over time, the financial support of the ST system ceased to be the sole prerogative of the central government. Regional governments, which have a closer connection to local enterprises and non-state enterprises, have been investing in $\mathrm{R} \& \mathrm{D}$ and facilitating the establishment of industrial parks and incubators, with a peak in richer coastal regions. Their commitment is justified by the benefits they

\footnotetext{
121 Zhou and Liu, in: Zhou et al. (eds.) (2016), p. 45, arguing that the shift towards government funding was a reflection of China's high growth rate and increased budget and an attempt to emulate the knowledge economy phenomenon in the West.

122 Cao et al. (2006). State Council of the People's Republic of China: The National Medium- and LongTerm Program for Science and Technology Development (2006-2020). An Outline. (hereinafter referred to as "MLP").

123 Shao (2013).

124 MLP, supra note 122, Sec. VIII.2.

125 Zhou and Liu, in: Zhou et al. (eds.) (2016), p. 46.

126 Ibid., p. 47. Linga and Naughton (2016).

127 Zhou and Liu, in: Zhou et al. (eds.) (2016), p. 47.

128 Ibid., pp. 47-48, which points out that the devoting of fewer resources to basic research may be explained by the fact that China was primarily interested in catching up with predominantly Western technology. On the other hand, it may also be a legacy of the bureaucratic ST system, which was more inclined towards implementation than stimulating creativity. As to the importance of basic research in the IT industry, see Theis and Horn (2003). See also UNESCO (2016), p. 625.
}

129 Huang (2018). 
may reap with regard to competition for central government funding and attracting specialized labour forces. ${ }^{130}$

The involvement of non-state firms in China's ST is another factor to consider. Although there is consensus that state-owned enterprises (SOEs) have been the main recipient of industrial policy-related funds (compared to non-state firms), ${ }^{131}$ the reality suggests a mixed state of affairs that depends on industries and regions. Overall, non-state enterprises experienced faster growth than foreign firms and SOEs, although the latter retained more power and control in important segments of the economy and in resource-intensive industries in particular (petrochemical, power, national defence, finance, transportation, mining, metallurgy, and machinery). Most importantly, however, a trend has emerged in which non-state Chinese firms have channelled their investments into technology assimilation and in-house technological improvement, which may be seen as symptomatic of China's improved innovation capacity. ${ }^{132}$ This assumption has also been reinforced by China's increased participation in international standard-setting activities and in the development of $3 \mathrm{G}, 4 \mathrm{G}$, and $5 \mathrm{G}$ technologies. ${ }^{133}$

There are several reasons as to why innovation has become a crucial matter for China, in particular in the past decade. Since the opening-up reforms over the past 30 years or so, Chinese economic development has been sustained by a set of circumstances that includes a workforce with a favourable dependency ratio and lower wages. Since 2010-2012, however, the Chinese economy has begun to slow down. The reasons for this may be linked on the one hand to the slowdown of the global economy; on the other hand, wages have been increasing, coupled with a less favourable shift in workforce demographics. ${ }^{134}$ The Chinese economy has thus been at a crossroads, and the pursuit of technological/industrial upgrade and innovation has been identified as a possible way out. But how effective has this been? Although innovation is difficult to quantify, there is consensus on certain factors. First, by 2014, Chinese expenditure on R\&D amounted to $2.05 \%$ of its GDP, above the $1.9 \%$ average of OECD countries. ${ }^{135}$ Second, the share of researchers and scientists in the population has increased over time. ${ }^{136}$ Considering firm ownership, R\&D expenditure and the hiring of scientists in non-state enterprises has surpassed that of SOEs. ${ }^{137}$ Third, China's accomplishment as regards scientific article output and relevance, as well as patent filing and quality, is noteworthy. ${ }^{138}$ Where patent filing

\footnotetext{
$\overline{130}$ Zhou and Liu, in: Zhou et al. (eds.) (2016), p. 47.

131 Breslin (2011), labelling this phenomenon as "expansion of the state and retreat of non-state". Naughton (2011). Wei et al. (2017), pp. 64-67. Xie et al. (2014), p. 9441. Mitchell et al. (2019).

132 Wei et al. (2017), p. 49.

$133 \mathrm{Yu}$ (2011a). Stewart et al. (2011).

134 Wei et al. (2017), p. 49.

135 Ibid., p. 58.

136 Ibid., p. 59. Xie et al. (2014), p. 9437.

137 Wei et al. (2017), pp. 58-59. Zhou and Liu, in: Zhou et al. (eds.) (2016), p. 56. At p. 58, the authors point out that, after 2009, the number of R\&D labs and institutes within non-SOEs has progressively increased.

138 Xie et al. (2014), pp. 9439-9441. Wei et al. (2017), pp. 60-63.
} 
and quality is concerned, SOEs are performing less well than non-state and foreign firms. ${ }^{139}$ Nevertheless, a closer look reveals that the main share is represented by utility and design patents rather than innovation patents. ${ }^{140}$ This suggests not that innovation is absent in China but rather that much of it is still incremental in nature and a manifestation of the specialization of Chinese firms (especially IT ones) in product assembly. Although sophisticated ICT production exists in China and companies like Huawei and ZTE are able to compete with other technology giants, China's progress in areas such as the operating system software architecture and semiconductor chip design is ongoing. ${ }^{141}$

\subsubsection{Standardization}

The re-established role of the Chinese State in ST has raised concerns about resurging protectionism and discriminatory practices against foreign companies. However, a cautious reading of the facts shows that post-WTO China is different from isolationist China and that techno-nationalistic policies clash with the development of a globally integrated market economy and international trade commitments. ${ }^{142}$

As for innovation policies, the Chinese State has been crucial in the development of a strategy on standardization and IPR. While prior to joining the WTO China had been an eager adopter of prevailing international standards, in the early 2000s policymakers realized the intertwined nature of standards and IPRs, which reinforced China's commitment to pursuing competing indigenous technical standards as a way to enable innovation and industrial upgrade. ${ }^{143}$

The literature has explained the rationale behind China's circuitous standardization strategy, underscoring: (i) how political decisions can influence technology development and tame market forces; (ii) how, on the other hand, the Chinese government has revealed internal tensions, resulting in its support for certain standards and its abandonment of others; and (iii) how firms, research institutes, and universities have adapted to this frantic and uncertain environment. ${ }^{144}$ Overall, the literature suggests that China's approach to standard-setting has been disjointed rather than homogeneous or mercantilist: ${ }^{145}$ on the one hand, the Chinese government has pursued the creation of distinct standards, especially in the ICT domain; on the other, however, it has also been an active participant in international standard-setting organizations. Likewise, Chinese companies that paid high royalties to foreign SEP holders have objected to the development of mandatory domestic standards, while companies with considerable exports, which would

\footnotetext{
139 Zhou and Liu, in: Zhou et al. (eds.) (2016), p. 60. Wei et al. (2017), p. 63.

140 Center for Strategic and International Studies (CSIS), China Power Project (2020).

141 Sun and Grimes (2016), p. 211.

142 Zhou and Liu, in: Zhou et al. (eds.) (2016), p. 51.

143 Passim, Murphree and Breznitz (2013) and Breznitz and Murphree (2011). Ping (2013).

144 Breznitz and Murphree (2011), p. 10. Ernst (2011), pp. 28-32.

145 Generally, Suttmeier and Yao (2004); Suttmeier et al. (2006).
} 
undoubtedly benefit from international standards, have participated in the development of standards that apply to China exclusively. ${ }^{146}$

China's standardization strategy, characterized by government financial support and the adoption of competing standards, is contingent on its innovation system and economy. To summarize briefly, China has not benefited from international standardization because the majority of its production activity has relied on foreign technology and is centred on the final assembly stage of products with components that are made abroad. This has made Chinese firms low-margin/high-volume manufacturing businesses, placing them in a lower position in the global production system. Royalties have always been an issue for manufacturers: while intense competition has reduced the price of goods, royalty rates have remained constant. As such, profit margins have decreased. Stimulating the creation of indigenous competing standards to acquire technological independence has also had an effect on negotiating lower royalties for foreign IPRs. ${ }^{147}$

At the same time, the legal basis of China's standardization system began to show its weaknesses. As mentioned above, the Chinese government's decisionmaking is not monolithic but rather performed by multi-decision-making bodies and, as such, is fragmented: top-down decisions intersect with horizontal-level decisions. ${ }^{148}$ This had implications for the standardization system, which became fragmented, dispersed, and uncoordinated. ${ }^{149}$ To address the confusion, the State Council issued a series of measures: the "Plan for Furthering the Standardization Reforms"; ${ }^{150}$ the "Coordinated Promotion of Joint Inter-ministerial Meeting System for Standardization"; 151 and the "action plan for implementing the Plan for Furthering the Standardization Reforms" (2015). ${ }^{152}$ These measures underscored that the standardization system was restraining the ability of enterprises to contribute to innovation ${ }^{153}$ and hence that it was necessary to implement reform with government deregulation as a precondition, ${ }^{154}$ putting emphasis on enterprise and association standards and allowing the participation of stakeholders according to principles such as openness, transparency, and consensus.

\footnotetext{
146 Ibid., passim.

147 Breznitz and Murphree (2011), p. 10.

148 Wang and Liang (2016), p. 10. Suttmeier et al. (2006), p. 31.

149 Wang and Liang (2016), p. 10. Ernst (2011), p. 28.

150 Notice of the State Council on Printing and Distributing the Reform Plan for Deepening Standardization Work, Guofa [2015] No. 13.

151 The State Council: Coordinated Promotion of Joint Inter-ministerial Meeting System for Standardization, June 2015.

152 The State Council: on the issuance of the action plan for implementing the Plan for Furthering the Standardization Reforms, Guo Ban Fa [2015] No. 67.

153 Wang and Liang (2016), p. 12.

154 Ibid.
} 
2.2.1.1 The Standardization Law The standardization law was revised and came into effect in 2018. ${ }^{155}$ The new legislation streamlines the standardization system, providing a clear distinction between mandatory and voluntary standards. It also aims to promote the application of scientific and technological achievements, to enhance the security and interoperability of products, and to prevent standards from being used to impair the free flow of goods and services or to restrain market competition. ${ }^{156}$ It also encourages participation in international standard-setting activities and the adoption of international standards. ${ }^{157}$

National standards are divided into those that are mandatory and those that are voluntary. Standards that are issued to provide technical requirements to (i) safeguard human health, safety, and property; (ii) protect national security and the environment; and (iii) meet the basic needs of social and economic management fall into the first category. ${ }^{158}$ On the other hand, voluntary national standards may be developed to address technical requirements that are necessary for meeting basic and general purposes, to complement mandatory national standards, or to guide the relevant industries. ${ }^{159}$ Recommendations to adopt mandatory national standards may be submitted by ministries, local governments, social organizations, enterprises, public institutions, and citizens. ${ }^{160}$

Industry and local standards are now solely voluntary. The law introduces a mechanism to coordinate the development and implementation of these standards, avoid overlap, and settle disagreements. ${ }^{161}$

Finally, there are two categories of private and market-led standards: enterprise standards ${ }^{162}$ and group/association standards. ${ }^{163}$ The new legislation encourages the adoption of these standards by streamlining certain bureaucratic aspects. Instead of reporting the standard to the relevant government department for record-keeping purposes, companies must disclose, on a dedicated online platform, the standards they will implement. ${ }^{164}$ Along the same lines, the law recognizes the legal status of standards adopted by social groups (academies, associations, chambers of commerce, and federations). In this regard, the role of the government is to regulate, guide, and supervise the development of these standards, not to initiate the standardization process. ${ }^{165}$ The development of association standards is informed by

\footnotetext{
155 Liu (2018b). The Standardization Law of the People's Republic of China, revised and adopted at the 30th Meeting of the Standing Committee of the Twelfth National People's Congress on 4 November 2017, promulgated and entered into force on 1 January 2018 (2018 Standardization Law).

1562018 Standardization Law, Art. 22.

157 Art. 8.

158 Art. 10. Compliance with compulsory national standards is a prerequisite for achieving the certification required for placing products on the Chinese market.

159 Art. 11.

160 Art. 10.

161 Arts. 6 and 33.

162 Art. 19.

163 Art. 18.

164 Art. 27. http://www.cpbz.gov.cn/.

165 Art. 18.
} 
the principles of openness, transparency, and fairness, ${ }^{166}$ and welcomes the use of indigenous technologies. ${ }^{167}$

The reformed law also envisions the establishment of a system to monitor the implementation of mandatory standards and a feedback/evaluation system for voluntary standards, which will serve the purposes of planning standard reviews ${ }^{168}$ and handling overlaps. ${ }^{169}$ Liability arising from non-compliance with standards and the use of standards for anticompetitive purposes $^{170}$ are addressed in the final section of the legislation.

Although the reform was adopted only recently, additional instruments are shaping the Chinese standardization regulatory landscape, including the Mandatory National Standards Management Measures and the Management Regulations for Association Standards, ${ }^{171}$ the "Opinions on Implementing a 'Pioneer'/'Frontrunner' System for Enterprise Standards", ${ }^{172}$ and the "Guiding Opinions on ForeignInvested Enterprises' (FIE) Participation in China's Standardization Work". ${ }^{173}$ The latter measure is of particular interest as it provides that foreign-invested enterprises can participate in standardization work in China - e.g. drafting national standards, translating them into foreign languages, joining TCs as members or observers - and enjoy the same treatment as domestic firms.

The recent government overhaul has established seven new ministries, and with regard to the institutional architecture of standardization, the State Administration of Market Regulation (SAMR) has absorbed the functions of the AQSIQ, restructured the SAC - creating a department of standard technology management (in charge of standardization strategy, the adoption of international standards, and the management of national TCs) and a department of standard innovation (in charge of social association standards, local standards, company standards, participation in international standards development, and cooperation with the

\footnotetext{
166 Ibid. Openness may be understood as a party's ability to participate in the standard development process. Transparency, on the other hand, is related to the availability of information regarding SSOs' internal processes. Fairness relates to the standard-setting process itself, where non-discrimination, impartiality, and the balancing of interests should prevail.

167 Art. 20.

168 Art. 29.

169 Art. 30.

170 Arts. 36, 37 and 39.

171 SAMR, "Mandatory National Standard Management Measures", 13 December (2019) (effective as of 1 June 2020). SAMR, "Interpretation of the 'Mandatory National Standard Management Measures", 17 January (2020). The interpretation underlines that the new measures were necessary, as the "National Standard Management Measures" issued by the China State Bureau of Technical Supervision on 24 August (1990) were outdated. Standardization Administration of China, Ministry of Civil Affairs, "Management Regulations for Association Standards", 9 January (2019).

172 State Administration of Market Regulation, National Development and Reform Commission, Ministry of Science and Technology, Ministry of Industry and Information Technology, Ministry of Finance, Ministry of Ecology and Environment, Ministry of Transport, People's Bank of China, "Opinions on Implementing the Forerunner Rules for Enterprise Standards", 28 June (2018).

173 Standardization Administration of China, National Development and Reform Commission, and the Ministry of Commerce, "Guiding Opinions on Foreign-Invested Enterprises' Participation in China's Standardization Work", 13 November (2017).
} 
ISO and the IEC) - and streamlined the management of the State Intellectual Property Office (SIPO), now renamed China National Intellectual Property Administration (CNIPA). ${ }^{174}$

In terms of economic and innovation impact, the success of the new reform will depend on the extent to which government support (in particular, financial support for particular standardization projects and implementation support) can be balanced with the openness of the standard project to both foreign and domestic stakeholders. ${ }^{175}$

\subsubsection{Planning Development: IPRs and Innovation}

Following its accession to the WTO, China prioritized strengthening IPR enforcement. The role of Chinese leaders - through speeches and position papers - was a determining factor in steering the institutional and political component of the country towards realizing the importance of IPRs as a strategic economic tool. ${ }^{176}$ Soon after China's accession to the WTO, US pressure ceased, and there was little support from outside China when it came to raising awareness in Chinese society of the importance of IPRs, ${ }^{177}$ a gap which was filled by local businesses and trade/industry associations. ${ }^{178}$ Chinese society also became aware of the perils of inadequate IPR protection in terms of trade, economic performance, development, ${ }^{179}$ and international reputation.

Planning played an additional role in capacity-building. Chinese innovation and IP strategy has its core in the 2006 MLP, which set crucial objectives for building the country's capabilities in science and technology. ${ }^{180}$ Patent filing and development of standards are considered to be of the utmost importance, as a company's IP

\footnotetext{
174 Tiezzi (2018). Seconded European Standardization Expert in China Project (2018). Following the restructuring, SIPO was renamed China National Intellectual Property Administration (CNIPA), on 28 August 2018.

175 Murphree and Breznitz (2018), p. 235. However, much will also depend on the strategic decisions of foreign firms when it comes to participating in Chinese standard-setting projects. Gao et al. (2014). Yu et al. (2014).

$176 \mathrm{Yu}(2004)$, p. 5.

177 Alford (1997), p. 142, notes that although it is a matter of concern, "neither the U.S. government nor many of the companies driving [the American foreign intellectual property] policy [...] have made any substantial attempt $[\ldots]$ to communicate to the Chinese why better intellectual property protection would be in their interest". Chow (2000), p. 46, notes that "brand owners are reluctant to commit the amount of resources necessary to achieve these goals or to risk seriously offending the Chinese government". Hu (1996), p. 111, notes that "active involvement by U.S. companies and lawyers, for example through special seminars, exchange programs, mock proceedings, and other assistance to the Chinese media, will expedite the training process". Griffin (1998), p. 190, claims that "U.S. companies must take a proactive stance and not be content to rely on government for help".

$178 \mathrm{Yu}$ (2004), p. 7, offers as an example the joint effort by the Business Software Alliance and the Chinese Software Alliance promoting the use of original software in China.

${ }^{179} \mathrm{Yu}(2000)$, pp. 189-190. Yu (2001), p. 61.

${ }^{180}$ Gerst (2015), p. 19.
} 
and standards' record influences its eligibility for a range of benefits (tax cuts, subsidies, and so forth). ${ }^{181}$ The MLP was complemented by the "National Intellectual Property Strategy" (2008), which set key measures for addressing several IPR-related issues, emphasizing the importance of creating, using, and protecting rights, especially in the context of standardization. ${ }^{182}$ IPRs are identified as a strategic resource for both national development/innovation and international competitiveness. ${ }^{183}$ Finally, the "Action Plan for Further Implementation of the National IP Strategy (2014-2020)" was issued on 29 December 2014. ${ }^{184}$ The Plan sets three main objectives: (i) to make China a key promotor of IPRs, (ii) to create an environment in which IPRs are better utilized and protected, and (iii) to promote the creation and development of IP-intensive industries. The measures outlined above paved the way for a shift in the Chinese developmental model towards a new emphasis, as laid down in the thirteenth five-year plan, ${ }^{185}$ on the importance of knowledge and technology.

\subsubsection{Measures Addressing IPRs in Standards}

China's policy on standard-related IPRs began to emerge following China's accession to the WTO. ${ }^{186}$ This policy does not take a univocal approach, however; instead, it is a compromise between the government's vision and the sometimes diverging interests of Chinese firms and SSOs. ${ }^{187}$ It is therefore necessary to consider the interplay of three different levels: (i) state regulation and policies; (ii) standard-setting bodies' IPR policies; and (iii) case law.

The first measure addressing patents and standards dates back to the early 2000s. In 2003, the Ministry of Information Industry (MII) issued a draft policy to clarify certain aspects pertaining to the treatment of patents in standardization. The policy did not make a distinction between essential and non-essential patents and, in the case of mandatory standards, provided for compulsory patent pool participation. Foreign stakeholders, who at the time had limited access to standardization working groups, did not receive the draft policy with enthusiasm. ${ }^{188}$ In parallel, and in support of the MII's draft policy's content, the China Electronics Standardization Institute (CESI) expressed concerns about the standards and IP issue, along with possible solutions. ${ }^{189}$ In the view of the CESI, China was trapped in a new form of 
non-tariff barrier (an "IP-centric technology barrier"). In brief, because Western countries cannot compete with lower Chinese production costs, CESI argued that the former were using an elaborate set of barriers based on the existing international rules to hinder the progress of developing countries. Initially, IPRs were included in WTO rules so as to spread Western IPR protection standards; ${ }^{190}$ afterwards, IPRs were embedded in the standardization process. As a whole, this impinged on developing countries' exports. ${ }^{191}$

Although the arguments above are largely from the Chinese government's point of view, on the other side of the Chinese standardization spectrum, the Audio Video Coding Standard Working Group of China (AVS) drafted a patent policy based on what was perceived as "best practice", welcoming the contributions of foreign companies to the drafting process. ${ }^{192}$ Both foreign stakeholders and the Chinese standardization community welcomed this effort, as it proactively addressed a problem common to SSOs. The AVS's patent policy requires members to abide by its provisions, ${ }^{193}$ to disclose known standard-related patents, and to make an ex ante commitment to license on FRAND or FRAND-RF terms or to participate in the AVS patent pool. ${ }^{194}$ In 2006, AVS released the "Advisory Guidelines for Patent Pool License of AVS Standards" (which provides a royalty fee of one RMB Yuan per unit) for consumer-level encoders/ decoders within the territory of the People's Republic of China. ${ }^{195}$

The AVS's attempt to accommodate private interests and social benefits in the IT standard-setting process served as a basis for the CESI's IT Standard Drafting Organizations' IPR Policy Template ${ }^{196}$ (an effort to emulate internationally recognized best practices and to provide a guideline for Chinese SSOs that were developing their own IPR policies) and for the IPR policy of the China Communications Standards Association (CCSA) (a standardization body under the Ministry of Industry and Information Technology, MIIT) in $2007 .^{197}$

These initiatives predate a formal government attempt to formulate national policy guidelines. The SAC issued several draft regulations ("Proposed Regulations for the Administration of the Formulation and Revision of Patent Involving National Standards") on standardization and patents, progressively adjusting the aim. ${ }^{198}$ These drafts have a core concept in common: patents and mandatory national standards are not compatible. ${ }^{199}$ A final version of the draft was released jointly by

\footnotetext{
$\overline{190}$ China Electronics Standardization Institute (2003).

191 Ibid.

192 Maskus and Merrill (eds.) (2013), p. 126. Ernst (2011), p. 93, points out that the AVS Working Group was organized in 2002 in order to respond to the high royalty fees paid by Chinese DVD manufacturers using the MPEG-2 standard.

193 AVS Patent Policy, Art. 2.

194 Art. 14. If a patent has been granted in China, only the latter two options are available.

195 AVS Advisory Guidelines for Patent Pool License of AVS Standards, Art. IV(2).

196 Maskus and Merrill (eds.) (2013), p. 127.

197 Ibid., p. 128. The Ministry of Industry and Information Technology superseded the Ministry of Information Industry.

198 McElwain (2016), p. 454. Sokol and Zheng (2013), p. 82.

199 McElwain (2016), p. 455. Sokol and Zheng (2013), pp. 82-85.
} 
the SAC and the SIPO in 2014 ("Interim Regulatory Measures on National Standards Involving Patents"). ${ }^{200}$ Although they were welcomed with greater optimism, the measures still embody the concept that patents and standardization are largely incompatible. ${ }^{201}$

The Interim Measures provide for obligations in relation to the disclosure of SEPs in the revision and formulation of national standards and target individuals and organizations that have (and have not) participated in such processes. Those who have participated are required to disclose known patents, while those who have not are invited to notify the relevant $\mathrm{TC}$ or the responsible entity of such information at any stage in the formulation or revision of the standard. ${ }^{202}$ The definition of essential patents is broad: it picks out any patent that is involved in a national standard and that is required for that standard's implementation. ${ }^{203}$

The Interim Measures govern the SEP licensing phase, providing three main options: (i) FRAND-RF; (ii) FRAND; and (iii) no licence. ${ }^{204}$

Concerning the relation between mandatory national standards and patents, in principle, this typology of standards must not involve patents. ${ }^{205}$ If the inclusion of a patent in a mandatory national standard cannot be avoided, however, the SAC, the SIPO and the patent holder will enter into negotiations to resolve the matter. If an agreement cannot be reached, the national standard will be put on hold and will not be authorized for publication. ${ }^{206}$ As a precaution, before allowing the publication of a national mandatory standard involving a patent, the SAC will publish the full text of the standard, along with the known patent information, for a period of 30 days in order to allow any organization or individual to notify the SAC of any additional patent information. ${ }^{207}$

The fourth revision of the Chinese Patent Law considers SEP licensing. ${ }^{208}$ A patent holder who does not disclose a patent that is essential to a standard during the process of formulating a national standard is deemed to permit implementers to make use of said patent, provided that a licence fee is negotiated between patent holder and implementer. If such negotiation fails to reach an outcome, the SIPO will adjudicate the case, and the dissatisfied party will have the right to appeal before the

\footnotetext{
200 SAC, SIPO (2014), Interim Regulatory Measures on National Standards Involving Patents (hereinafter referred to as "Interim Measures").

201 McElwain (2016), p. 456.

202 Interim Measures, Sect. II, Arts. 1 and 2. These measures are complemented by the GB/T 20003.12014 ("The Special Procedures of Standards Formulation - Part 1: Standards Involving Patents"), which covers the practical aspects of standardization, in particular the formulation or revision of standards involving patents.

203 Sect. I, Art. 4

204 Sect. III, Art. 1. Although the FRAND commitment is a common aspect of SSOs' IPR policies, it remains to be seen how the SAC will interpret the word "reasonable". McElwain (2016), p. 456.

205 Sect. IV, Art. 1.

206 Sect. IV, Art. 2.

207 Sect. IV, Art. 3.

208 Huihui (2015). Mak (2018). As to the developments in the Chinese IPR landscape, one may follow Mark Cohen's blog “China IPR”. https://chinaipr.com/.
} 
People's Court within three months. Additionally, the proposed (draft) revision introduces a "licence as of right" mechanism, following the example of jurisdictions such as Germany, Italy and the United Kingdom. However, these amendments are in a draft phase. As such, a more consistent and reasoned appraisal of the provisions thereof (if maintained) should be undertaken after the new patent law will be enacted.

Standard-essential patents are considered by China's anti-monopoly law, Guidelines on Abuse of Intellectual Property Rights, issued on 23 March 2017 and scheduled to become operative by the end of $2019 .^{209}$ Two provisions are relevant: Arts. 13 and 26. The first provision addresses the relation between holding IPRs and possessing a dominant position in the market, pointing out additional factors that ought to be considered when standard-essential patents are involved (such as market value, the scope and extent of the standards, and the degree of the industry's dependence on those standards). The second provision addresses the availability of injunctive relief when standard essential patents are concerned, focusing on behaviour during negotiations, licensing conditions, and the impact of the injunction on the licensing process.

Ultimately, the Chinese courts have contributed to shaping the landscape of Chinese IP and standards. Cases such as Huawei $v$ IDC have explored the content of the FRAND commitment, and cases such as IWNCOMM $v$ Sony and Huawei $v$ Samsung have explored the availability of injunctive relief. ${ }^{210}$ These cases are not the topic of this paper, however, and deserve a separate, in-depth discussion.

\section{Conclusion}

Historically, the Chinese State has had a decisive stake in national innovation matters. The ST system has also undergone rapid change, transitioning from a centralized, Soviet-inspired system in the 1950s to an open, enterprise-driven model in the 1980s and 1990s, where export promotion and TMFT policies were important components. From the 2000s onward, China has intensified its integration with global production systems. Nevertheless, Chinese policymakers perceived the weakness of China's innovative capacity as a factor that hindered its development. Consequently, starting from 2006, the Chinese State took on a stronger role in ST through the indigenous innovation policy, an essential feature of which has been the participation of enterprises, including non-state and foreign enterprises. This policy should be read not in terms of techno-nationalism but rather in terms of pragmatism.

\footnotetext{
209 http://www.nipso.cn/onews.asp?id=35439.

210 Huawei v InterDigital, judgments of 28 October 2013, Guangdong Higher People's Court of China, Nos. 305 and 306; IWNComm Co Ltd v Sony Mobile Communications Products (China) Co Ltd (infringement of patent dispute case), Beijing Intellectual Property Court, First Instance Decision No. 1194, 22 March 2017; and Sony Mobile Communications Products (China) Co Ltd v IWNComm Co Ltd (second instance civil judgment in infringement of patent dispute case), Beijing Municipal Higher People's Court, Final Instance Beijing Civil Court Decision No. 454, 28 March 2018; Huawei Technologies Co Ltd v Samsung (China) Investment Co Ltd (infringement of patent dispute case), Guangdong Shenzhen Municipal Intermediate People's Court, First Instance Decision No. 816, 4 January 2018.
} 
Because of international commitments and the increasing delocalization of production processes, China must maintain an innovation system that is aligned with international practices and open to (foreign) non-state enterprises; at the same time, maximizing technology absorptive capacity is essential to remaining competitive.

The above considerations lay the ground for reflecting on China's approach to standardization and IPRs. Standardization is essential to China's national innovation strategy, and the creation of standards, along with participation in international SSOs, has been a critical factor since the 2000s. Standardization is in fact a platform for promoting technology transfer and industrial upgrade, which is essential to the catching-up process and technological emancipation. The recent reform of the Standardization Law, which has reinforced the role of bottom-up standardization and the participation of (foreign) stakeholders, should be read along these lines, although it remains to be seen how this will play in the long run.

In parallel, the evolution of China's IPR policy regarding SEPs has demonstrated, although not unequivocally, a shift of attention to international norms and stakeholders, although China's attitude toward IPRs in standardization may still be sensitive to the role of IPRs in the production process (in short, as a cost). This policy is continuing to evolve, however, and reflects a common problem on different levels, i.e. accommodating divergent interests and different goods (public, standards; private, patents). A key element in the evolution of this policy is the transformation of the profile of Chinese patent holders: from universities and research centres driven by motives such as prestige ${ }^{211}$ to companies, which are more sensitive to market dynamics. In this regard, fleshing out the enforcement of SEPs in Chinese courts and the results of recent cases brought against China by the EU and the US before the WTO constitutes an important litmus test and direction of future research.

Due to the acute pragmatism underlying China's innovation policy, companies should resort to risk management tools to properly manage their intellectual property assets in China.

Acknowledgements I wish to express my gratitude to the organizers of the IPIRA and the China-EU School of Law PhD workshop on recent developments in Chinese law. My thanks also go to Dr. Jingjing $\mathrm{Wu}$ for her valuable help in translating the passage quoted in note 173. Last but not the least, I am indebted to Dr. Stéphanie Bijlmakers for her patient reading of an earlier version of this paper and for providing useful comments, and to Carolyn Benson (language polishing) for helping to prepare this piece for publication. For its research on competition, standardization, and innovation, TILEC has received funding from Qualcomm Inc., which is gratefully acknowledged. The author declares that he has no affiliations with, or involvement in, any organization or entity with any financial interest, or non-financial interest in the subject matter or materials discussed in this manuscript.

$\overline{211}$ McElwain (2016), p. 458. Breznitz and Murphree (2013), pp. 29-32. 
Open Access This article is licensed under a Creative Commons Attribution 4.0 International License, which permits use, sharing, adaptation, distribution and reproduction in any medium or format, as long as you give appropriate credit to the original author(s) and the source, provide a link to the Creative Commons licence, and indicate if changes were made. The images or other third party material in this article are included in the article's Creative Commons licence, unless indicated otherwise in a credit line to the material. If material is not included in the article's Creative Commons licence and your intended use is not permitted by statutory regulation or exceeds the permitted use, you will need to obtain permission directly from the copyright holder. To view a copy of this licence, visit http:// creativecommons.org/licenses/by/4.0/.

\section{References}

\section{Journal Articles}

Alford WP (1997) Making the world safe for what? Intellectual property rights, human rights and foreign economic policy in the post-European cold war world. N Y Univ J Int Law Politics 29(1):135-152

Breslin S (2011) China and the crisis: global power, domestic caution and local initiative. Contemp Politics 17(2):185-200

Burke FR (1987) The administrative law of standardization in the PRC. J Chin Law 1(2):270-300

Cao C, Suttmeier RP, Simon DF (2006) China's 15-year science and technology plan. Phys Today 59 (12):38-43

Chow DCK (2000) Counterfeiting in the People's Republic of China. Wash Univ Law Q 78(1):1-57

Ernst D, Lee H, Kwak J (2014) Standards, innovation, and latecomer economic development: conceptual issues and policy challenges. Telecommun Policy 38(10):853-862

Fischer AM (2010) Is China turning Latin? China's balancing act between power and dependence in the lead up to global crisis. J Int Dev 22(6):739-757

Gao X, Liu J (2012) Catching up through the development of technology standard: the case of TDSCDMA in China. Telecommun Policy 36(7):531-545

Gao X, Gerst M, Sun R (2014) Understanding MNEs' decline in the adoption of locally developed technology standard in China: a positioning and cognitive perspective. Telecommun Policy 38 (10):878-899

Gibson CS (2007) Globalization and the technology standards game: balancing concerns of protectionism and intellectual property in international standards. Berkeley Technol Law J 22(4):1403-1484

Griffin EM (1998) Note, stop relying on Uncle Sam! A proactive approach to copyright protection in the People's Republic of China. Texas Intellect Prop Law J 6(2):169-197

Hu PH (1996) "Mickey Mouse" in China: legal and cultural implications in protecting U.S. copyrights. Boston Univ Int Law J 14(1):81-117

Huihui L (2015) Introduction to the fourth revision of Chinese patent law. China Pat Trademark 3:59-65

Kshetri N, Palvia P, Dai H (2011) Chinese institutions and standardization: the case of government support to domestic third generation cellular standard. Telecommun Policy 35(5):399-412

Linga C, Naughton B (2016) An institutionalized policy-making mechanism: China's return to technoindustrial policy. Res Policy 45(10):2138-2152

McElwain C (2016) The world's laboratory: China's patent boom, IT standards and the implications for the global knowledge economy. Santa Clara J Int Law 14(2):441-460

Murphree M, Breznitz D (2013) Innovation in China: fragmentation, structured uncertainty and technology standards. Cardozo Law Review de novo 196-213

Naughton B (2011) China's economic policy today: the new state activism. Eurasian Geogr Econ 52 (3):313-329

Prud'homme D, von Zedtwitz M, Thraen JJ, Bader M (2018) "Forced technology transfer" policies: workings in China and strategic implications. Technol Forecast Soc Chang 134:150-168

Shao K (2013) Zizhu chuangxin and China's self-driven innovation: calling for a holistic perspective. Cardozo Law Review de novo 168-194

Sokol D, Zheng W (2013) FRAND in China. Texas Intellectual Property Law Journal 22(1):71-93 
Stewart J, Shen X, Wang C, Graham I (2011) From 3G to 4G: standards and the development of mobile broadband in China. Technol Anal Strateg Manag 23(7):773-788

Sun Y, Grimes S (2016) China's increasing participation in ICT's global value chain: a firm level analysis. Telecommun Policy 40(2-3):210-224

Theis TN, Horn PM (2003) Basic research in the information technology industry. Phys Today 56(7):4449

Viaille P, Song J, Zhang J (2012) Competing with dominant standards in a catching-up context. The case of mobile standards in China. Telecommun Policy 36(10-11):832-846

Wang P, Kwak J, Lee H (2014) The latecomer strategy for global ICT standardization: indigenous innovation and its dilemma. Telecommun Policy 38(10):933-943

Wei SJ, Xie Z, Zhang X (2017) From "made" in China to "innovated in China": necessity, prospects and challenges. J Econ Perspect 31(1):49-70

Wu J, Huang S (2008) Innovation or rent-seeking: the entrepreneurial behavior during China's economic transformation. China World Econ 16(4):64-81

Yu J (1994) Protection of intellectual property in the P.R.C.: progress, problems, and proposals. UCLA Pac Basin Law J 13(1):140-162

Yu J (2011a) From 3G to 4G: technology evolution and path dynamics in China's mobile telecommunication sector. Technol Anal Strateg Manag 23(10):1079-1093

Yu J, Zhang Y, Gao P (2014) Motivation and strategy: MNCs' embeddedness in China's standardizationbased innovation. Telecommun Policy 38(10):890-901

Yu PK (2000) From pirates to partners: protecting intellectual property in China in the twenty-first century. Am Univ Law Rev 50(1):131-243

Yu PK (2001) Piracy, prejudice, and perspectives: an attempt to use Shakespeare to reconfigure the U.S.China Intellectual Property Debate. Boston Univ Int Law J 19(1):1-87

Yu PK (2011b) The Middle Kingdom and the intellectual property world. Oregon Rev Int Law 13 (2):209-268

Zhang J, Yao F (2006) Technology transfer from the Soviet Union to the People's Republic of China 1949-1966. Comp Technol Transf 4(2):105-171

Zhao C, Graham JM (2006) The PRC's evolving standards system: institutions and strategy. Asia Policy 1 (2):63-87

Zhou Y (2008) Synchronizing export orientation with import substitution: creating competitive indigenous high-tech companies in China. World Dev 36(11):2353-2370

\section{Online Journal Articles}

Reeves M, He D (2015) What China's 13th five-year plan means for business. Harvard Bus Rev. https:// hbr.org/2015/12/what-chinas-13th-five-year-plan-means-for-business. Accessed 24 May 2020

\section{Articles by DOI}

Coe NM, Hess M, Wai-chung Yeung H, Dicken P, Henderson J (2004) "Globalizing" regional development: a global production networks perspective. Trans Inst Br Geogr 29(4):468-484. https:// doi.org/10.1111/j.0020-2754.2004.00142.x. Accessed 24 May 2020

Crookes PI (2012) China's new development model: analysing Chinese prospects in technology innovation. China Information 26(2):167-184. https://doi.org/10.1177/0920203X12445257. Accessed 24 May 2020

Ernst D, Kim L (2002) Global production networks, knowledge diffusion, and local capability formation. Res Policy 31(8-9):1417-1429. https://doi.org/10.1016/S0048-7333(02)00072-0. Accessed 24 May 2020

Huang W (2018) Advancing basic research towards making China a world leader in science and technology. Natl Sci Rev 5(2):126-128. https://doi.org/10.1093/nsr/nwy008. Accessed 24 May 2020

Liu X, Cheng P (2014) National strategy of indigenous innovation and its implication to China. Asian J Innov Policy 3(1):117-139. https://doi.org/10.7545/ajip.2014.3.1.117. Accessed 24 May 2020

Xie Y, Zhang C, Lai Q (2014) China's rise as major contributor to science and technology. PNAS 111 (26):9437-9442. https://doi.org/10.1073/pnas.1407709111. Accessed 24 May 2020 
Zhang L, Bruun N (2017) Legal transplantation of intellectual property rights in China: resistance, adaptation and reconciliation. IIC 48(1):4-41. https://doi.org/10.1007/s40319-016-0542-1. Accessed 24 May 2020

Zhou Y (2005) The making of an innovative region from a centrally planned economy: institutional evolution in Zhongguancun science park in Beijing. Environ Plan A Econ Space 37(6):1113-1134. https://doi.org/10.1068/a3716. Accessed 24 May 2020

\section{Online Newspaper/Blogs}

Baijie A (19 October 2017) Xi pledges "new era" in building moderately prosperous society. Chinadaily.com.cn. http://www.chinadaily.com.cn/china/2017-10/19/content_33428169_2.htm. Accessed 24 May 2020

Center for Strategic and International Studies (CSIS), China Power Project (2020) Are patents indicative of Chinese innovation? https://chinapower.csis.org/patents/. Accessed 24 May 2020

China IPR. https://chinaipr.com/. Accessed 24 May 2020

Mak T (2018) China: proposed revisions to the Chinese patent law. https:/www.mondaq.com/china/ patent/706042/proposed-revisions-to-the-chinese-patent-law. Accessed 24 May 2020

Mitchell T, Liu X, Wildau G (21 January 2019) China's private sector struggles for funding as growth slows. Financial Times. https://www.ft.com/content/56771148-1d1c-11e9-b126-46fc3ad87c65. Accessed 24 May 2020

Omoruyi EMM (13 March 2018) China's march towards a moderately well-off society. Chinadaily.com. cn. http://www.chinadaily.com.cn/a/201803/16/WS5aab21d6a3106e7dcc142020.html. Accessed 24 May 2020

Ross J (14 November 2012) "Moderately prosperous society" is key goal for China. China.org.cn. http:// www.china.org.cn/opinion/2012-11/14/content_27108452.htm. Accessed 24 May 2020

Ross J (30 October 2015) China's five-year plan to achieve a "moderately prosperous society". China.org. cn. http://www.china.org.cn/opinion/2015-10/30/content_36935303.htm. Accessed 24 May 2020

President Hu Jintao: Chinese R\&D needs more innovation. Asian Scientist Magazine (9 July 2012). https://www.asianscientist.com/2012/07/academia/chinese-president-hu-jintao-research-anddevelopment-innovation-2012/. Accessed 24 May 2020

The second Long March (11 December 2008) The Economist. https://www.economist.com/briefing/2008/ 12/11/the-second-long-march. Accessed 24 May 2020

Tiezzi S (2018) China's massive government overhaul: what you need to know. The Diplomat. https:// thediplomat.com/2018/03/chinas-massive-government-overhaul-what-you-need-to-know/. Accessed 24 May 2020

\section{Books}

Alford WP (1995) To steal a book is an elegant offense: intellectual property law in Chinese civilization. Stanford University Press, Stanford

Block FL, Keller MR (2011) State of innovation: the U.S. Government's role in technology development. Routledge, New York

Maskus K, Merrill SA (eds) (2013) Patent challenges for standard-setting in the global economy: lessons from information and communication technology. The National Academies Press, Washington

Mazzucato M (2013) The entrepreneurial state; debunking public vs. private sector myths. Anthem Press, New York

Snyder F (2015) Food safety law in China: making transnational law. Brill, Leiden

\section{Book Chapters}

Keller WW, Samuels RJ (2003) Innovation and the Asian economies. In: Keller WW, Samuels RJ (eds) Crisis and innovation in Asian technology. Cambridge University Press, Cambridge, pp 1-22 
Liu HW (2018a) China standard time: the boundary of techno-nationalism in megaregionals. In: Peng S, Liu HW, Lin C (eds) Governing science and technology under the international economic order regulatory divergence and convergence in the age of megaregionals. Edward Elgar, Cheltenham, pp 114-142

Suttmeier RP, Cao C (2004) China's technical community: market reforms and the changing policy cultures of science. In: Gu E, Goldman M (eds) Chinese intellectuals between state and market. Routledge Curzon, New York, pp 138-157

Zhou Y, Liu X (2016) Evolution of Chinese state policies on innovation. In: Zhou Y, Lazonick W, Sun Y (eds) China as an innovation nation. Oxford, New York, pp 33-67

\section{Laws/Regulations/Plans/Governmental Reports/Agency Newsletters/Standards}

China Electronics Standardization Institute (2003) Review on technology barriers related with intellectual property, info. tech. \& standardization, Sept. 2003, translated at: Simmtester.com, 17 Dec 2003. https://simmtester.com/News/PublicationArticle/103. Accessed 24 May 2020

China State Bureau of Technical Supervision (1990) National standard management measures, 24 August 1990. http://tradeinservices.mofcom.gov.cn/article/zhengce/flfg/201710/756.html. Accessed 24 May 2020

China, National intellectual property strategy (2008). http://www.gov.cn/gongbao/content/2008/content_ 1018942.htm. Accessed 24 May 2020

Chinese anti-monopoly law (2017) Guidelines on abuse of intellectual property rights, 23 March 2017. http://www.nipso.cn/onews.asp?id=35439. Accessed 24 May 2020

GB/T 20003.1-2014. The special procedures of standards formulation - Part 1: Standards involving patents

General Office of the State Council (1987) Report on accelerating the adoption of international standards, 25 February 1987. http://www.law-lib.com/lawhtm/1987/4148.htm. Accessed 24 May 2020

Interpretation of the "Mandatory national standard management measures", 17 January 2020. http://gkml. samr.gov.cn/nsjg/xwxcs/202001/t20200117_310567.html. Accessed 24 May 2020

ISO/IEC Guide 2:2004 - Standardization and related activities, general vocabulary

Notice of the State Council on printing and distributing the reform plan for deepening standardization work. Guofa [2015] No. 13. http://www.gov.cn/zhengce/content/2015-03/26/content_9557.htm. Accessed 24 May 2020

Regulation for Implementation of the Standardization Law, promulgated by Decree No. 53 of the State Council of the People's Republic of China on 6 April 1990 and effective as of the date of promulgation. http://www.cfstc.org/en/2932583/2968819/index.html. Accessed 24 May 2020

Standardization Administration of China (1984) Administration Statute for adopting international standards, 27 March 1984. http://www.110.com/fagui/law_144347.html. Accessed 24 May 2020

Standardization Administration of China, Ministry of Civil Affairs (2019) Management Regulations for association standards, 9 January 2019. http://images3.mca.gov.cn/www2017/file/201901/ 1547801421687.pdf. A translation is available at: https://www.sesec.eu/app/uploads/2019/01/ SESEC-IV-Management-Regulations-on-Association-Standards-201901018.pdf. Accessed 24 May 2020

Standardization Administration of China, National Development and Reform Commission, and the Ministry of Commerce (2017) Guiding opinions on foreign-invested enterprises' participation in China's standardization work, 13 November 2017. http://www.sac.gov.cn/szhywb/sytz/201711/ P020171130363181265870.pdf. A translation is available at: https://www.sesec.eu/app/uploads/ 2018/01/Annex-III-Guiding-Opinions-on-Participation-of-Foreign-Invested-Enterprises-inStandardisation-Work-of-China.pdf. Accessed 24 May 2020

Standardization Administration of China, State Intellectual Property Office (2014) Interim regulatory measures on national standards involving patents. http://www.sac.gov.cn/sxxgk/gkml/flfg/gnflfg/ 201512/t20151218_198752.htm. Non-official English translation at: https://web.archive.org/web/ 20150331014730/http://sunsteinlaw.com/wp/wp-content/uploads/2013/01/2013_01_IP_Update_ PRC.pdf. Accessed 24 May 2020

Standardization Law of the People's Republic of China, Adopted at the Fifth Meeting of the Standing Committee of the Seventh National People's Congress on 29 December 1988. http://www.asianlii. org/cn/legis/cen/laws/slotproc450/. Accessed 24 May 2020 
State Administration of Market Regulation (2019) Mandatory national standard management measures, 13 December 2019 (effective as of 1 June 2020). http://www.gov.cn/zhengce/zhengceku/2020-01/ 14/content_5468984.htm. Accessed 24 May 2020

State Administration of Market Regulation, National Development and Reform Commission, Ministry of Science and Technology, Ministry of Industry and Information Technology, Ministry of Finance, Ministry of Ecology and Environment, Ministry of Transport, People's Bank of China (2018) Opinions on implementing the forerunner rules for enterprise standard, 28 June 2018. http://www. sac.gov.cn/sfwyb/sytz_2087/201807/P020180720367828210769.pdf. Accessed 24 May 2020

State Administration of Market Regulation (2020) Interpretation of the "Mandatory National Standard Management Measures”, 17 January 2020. http://gkml.samr.gov.cn/nsjg/xwxcs/202001/t20200117_ 310567.html. Accessed 24 May 2020

State Bureau for Technical Supervision (1993) Measures for the administration of adoption on international standards and advanced foreign standards, 13 December 1993. http://law.foodmate.net/ show-163609.html. Accessed 24 May 2020

State Council of the People's Republic of China (2006) The national medium- and long-term program for science and technology development (2006-2020), an outline. https://www.itu.int/en/ITU-D/ Cybersecurity/Documents/National_Strategies_Repository/China_2006.pdf. Accessed 24 May 2020

The 13th five-year plan for economic and social development of the People's Republic of China (20162020). https://en.ndrc.gov.cn/newsrelease_8232/201612/P020191101481868235378.pdf. Accessed 24 May 2020

The Administration of Quality Supervision, Inspection and Quarantine (2001) Measures for the administration of adoption of international standards, 12 April 2001. http://www.fdi.gov.cn/ 1800000121_23_67693_0_7.html. Accessed 24 May 2020

The Standardization Law of the People's Republic of China, revised and adopted at the 30th Meeting of the Standing Committee of the Twelfth National People's Congress on 4 November 2017, entered into force on 1 January 2018. http://www.cfstc.org/en/2932583/2968817/index.html. https://www. sesec.eu/app/uploads/2018/01/Annex-I-China-Stadnardization-Law-20171104.pdf. Accessed 24 May 2020

The State Council (1979) Administration statute for national standardization, 31 July 1979. http://www. law-lib.com/lawhtm/1949-1979/43978.htm. Accessed 24 May 2020

The State Council (2015) Coordinated promotion of joint inter-ministerial meeting system for standardization, June 2015. http://www.gov.cn/gongbao/content/2015/content_2883233.htm

The State Council (2015) On the issuance of the action plan for implementing the plan for furthering the standardization reforms. Guo Ban Fa [2015] No. 67. http://www.gov.cn/zhengce/content/2015-09/ 10/content_10154.htm. Accessed 24 May 2020

The State Economic and Trade Commission (now Ministry of Commerce), State Scientific and Technological Commission (now Ministry of Science and Technology) and Standardization Administration (1982) Administration statute for adopting international standards (probation), 17 March 1982. http://www.110.com/fagui/law_352371.html. Accessed 24 May 2020

\section{International Agreements/Accession Status to International Agreements and Organizations}

Accession Status of the WIPO Convention. http://www.wipo.int/treaties/en/ShowResults.jsp?treaty_id=1. Accessed 24 May 2020

Agreement on Trade Relations Between the United States of America and the People's Republic of China, 7 July 1979. U.S.-P.R.C., 31 U.S.T. 4652

Agreement Regarding Intellectual Property Rights, 26 Feb 1995. P.R.C.-U.S., 34 I.L.M. 881 (1995)

Implementation of the 1995 Intellectual Property Rights Agreement, 17 June 1996. P.R.C.-U.S. https:// tcc.export.gov/trade_agreements/all_trade_agreements/exp_005361.asp. Accessed 24 May 2020

Memorandum of Understanding between China (PRC) and the United States on the Protection of Intellectual Property, 17 Jan 1992. P.R.C.-U.S. 34 I.L.M. 677 (1995) 


\section{Case Law}

Huawei v InterDigital, Judgments of 28 October 2013, Guangdong Higher People's Court of China, Nos. 305 and 306

Huawei Technologies Co Ltd v Samsung (China) Investment Co Ltd (Infringement of patent dispute case), Guangdong Shenzhen Municipal Intermediate People's Court, First Instance Decision No. 816, 4 January 2018

IWNComm Co Ltd v Sony Mobile Communications Products (China) Co Ltd (Infringement of patent dispute case), Beijing Intellectual Property Court, First Instance Decision No. 1194, 22 March 2017

Sony Mobile Communications Products (China) Co Ltd v IWNComm Co Ltd (Second instance civil judgment in infringement of patent dispute case), Beijing Municipal Higher People's Court, Final Instance Beijing Civil Court Decision No. 454, 28 March 2018

\section{Documents/Reports/Conference Papers/Working Papers/Bulletins}

Bertoldi M, Eriksgård Melander A, Weiss P (2016) Can economic transition be planned? China and the 13th Five-Year Plan. European Economy Economic Brief 017

Ernst D (2011) Indigenous innovation and globalization: the challenge for China's standardization strategy. UC Institute on Global Conflict and Cooperation-East-West Center

Ernst D (2013) Standards, innovation, and latecomer economic development. A conceptual framework. East-West Center Working Papers (Economic Series), No. 134

Hui L, Cargill CF (2017) Setting standards for industry: comparing the emerging Chinese standardization system and the current US system. East-West Center Working Papers (Policy Studies), No. 75

Kennedy S, Suttmeier RP, Su J (2008) Standards, stakeholders, and innovation: China's evolving role in the global knowledge economy. NBR Special Report No. 15

Liu H (2018) Analysis on change of formulation of standards in the new standardization law. In: Proceedings of the 2nd international conference on education, economics and management research (ICEEMR 2018). Advances in social science, education and humanities research (ASSEHR), Atlantis Press, vol. 182, pp 717-722

Murphree M, Breznitz D (2016) Standards, patents and national competitiveness. GCIG paper series, No. 40, CIGI-Chatham House

Murphree M, Breznitz D (2018) Indigenous digital technology standards for development: the case of China. J Int Bus Policy 1(3-4):234-252

Ping W, Yiyi W, Hill J (2010) Standardization strategy of China - achievements and challenges. EastWest Center Working Papers (Economic Series), No. 107

Springut M, Schlaikjer S, Chen D (2011) China's program for science and technology modernization: implications for American competitiveness. Research report prepared for the U.S.-China Economic and Security Review Commission

Suttmeier RP, Yao X (2004) China's post-WTO technology policy: standards, software, and the changing nature of techno-nationalism. National Bureau of Asian Research, Special Report No. 7, Seattle, WA

Suttmeier RP, Yao X (2011) China's IP transition: rethinking intellectual property rights in a rising China. NBR Special Report No. 29

Suttmeier RP, Yao X, Tan AZ (2006) Standards of power? Technology, institutions, and politics in the development of China's national standards strategy. The National Bureau of Asian Research, Special Report No. 10, Seattle, WA

UNESCO Science Report (2016) Towards 2030, Second revised edition 2016

Xu B (2006) Measuring the technology content of China's exports. China Europe International Business School, Working Paper 


\section{Online Documents/Reports/Conference Papers/Working Papers/Bulletins/ Statistics}

Breznitz D, Murphree M (2011) Standardized confusion? The political logic of China's technology standards policy. Paper presented at the Industry Studies Association Conference, Pittsburgh, PA, 2011. https://pdfs.semanticscholar.org/242b/38fb9697e9fa3eead6e02254b0d6bb94b11c.pdf?_ga=2. 120230986.359590319.1590330589-1177644516.1585997320. Accessed 24 May 2020

Breznitz D, Murphree M (2012a) Shaking grounds? Technology standards in China. Paper presented at the National Academy of Sciences Symposium on Management of Intellectual Property in StandardSetting Processes, 3-4 October 2012. https://sites.nationalacademies.org/cs/groups/pgasite/ documents/webpage/pga_072292.pdf. Accessed 24 May 2020

Breznitz D, Murphree M (2012b) China's run of the red queen - government, innovation, globalization and economic growth. Paper presented at the Ford Foundation Conference on Finance, Business Models, and Sustainable Prosperity, 6-7 December 2012, New York, NY. https://web.archive.org/ web/20170228081359/http://fiid.org/wp-content/uploads/2012/11/China\%E2\%80\%99s-Run-of-theRed-Queen-\%E2\%80\%93-Government-Innovation-Globalization-and-Economic-Growth.pdf. Accessed 24 May 2020

Breznitz D, Murphree M (2013) The rise of China in technology standards: new norms in old institutions. Research report prepared on behalf of the U.S.-China Economic and Security Review Commission (16 Jan 2013). https://www.uscc.gov/sites/default/files/Research/RiseofChinainTechnologyStandards. pdf. Accessed 24 May 2020

Chang HJ, Gershman J (2003) Kicking away the ladder: the "real" history of free trade. Special report, Foreign Policy in Focus. https://fpif.org/kicking_away_the_ladder_the_real_history_of_free_trade/. Accessed 24 May 2020

Ezell S, Atkinson R (2014) The Middle Kingdom Galapagos Island syndrome: the cul-de-sac of Chinese technology standards. Report prepared by the Information Technology and Innovation Foundation. https://itif.org/publications/2014/12/15/middle-kingdom-galapagos-island-syndrome-cul-de-sacchinese-technology. Accessed 24 May 2020

Gerst M (2015) IPR in standardization. IP Key report. https://ipkey.eu/sites/default/files/legacy-ipkeydocs/gerst_report_ipr-in-standards.pdf. Accessed 24 May 2020

IMF (2011) Changing patterns of global trade. http://www.imf.org/external/np/pp/eng/2011/061511.pdf. Accessed 24 May 2020

Information Office, State Council of the People's Republic of China (1994) Intellectual property protection in China. http://www.china.org.cn/e-white/intellectual/index.htm. Accessed 24 May 2020

McGregor J (2010) China's drive for "indigenous innovation": a web of industrial policies. Report commissioned by US Chamber of Commerce. https:/www.uschamber.com/sites/default/files/ documents/files/100728chinareport_0_0.pdf. Accessed 24 May 2020

OECD Science, Technology and R\&D statistics: main science and technology indicators, gross domestic spending on R\&D (2000-2018). https://data.oecd.org/rd/gross-domestic-spending-on-r-d.htm. Accessed 24 May 2020

Ping W (2013) Global ICT standards wars in China, and China's standard strategy. Paper presented at the workshop on "Asia's rise in global standardization", Yonsei University, Seoul, 19 April 2013. https://www.researchgate.net/publication/321862295_Global_ICT_standards_Wars_in_China_and_ China's_Standard_Strategy_1. Accessed 24 May 2020

Rongping M, Wu Z (2005) The role of standards in national technology policy in China. http:// strategicstandards.com/files/China.pdf. Accessed 24 May 2020

Seconded European Standardization Expert in China Project (2018) China government restructure in 2018 and its impact for standardization. https://www.sesec.eu/app/uploads/2018/08/SESEC-IVChina-Government-Restructure-in-2018-and-its-impact-for-standardization.pdf. Accessed 24 May 2020

Wang P, Liang Z (2016) Beyond government control of China's standardization system: history, current status and reform suggestions. Think piece for EWC-NSF workshop Mega-Regionalism-New Challenges for Trade and Innovation (MCTI), Honolulu, 20-21 January 2016. https://www. eastwestcenter.org/sites/default/files/filemanager/pubs/pdfs/6-3Wang-201607.pdf. Accessed 24 May 2020

Wei S, Professor of Finance and Economics, Wang NT, Professor of Chinese Business and Economy, Graduate School of Business, Columbia University (2012) Testimony before the U.S.-China 
Economics and Security Review Commission Hearing on the Evolving U.S.-China Trade and Investment Relationship, 14 June 2012. https://www.uscc.gov/sites/default/files/6.14.12Wei.pdf. Accessed 24 May 2020

World Bank, data on China. https://data.worldbank.org/country/china. Accessed 24 May 2020

World Bank, High-technology exports (current US\$), https://data.worldbank.org/indicator/TX.VAL. TECH.CD?locations $=$ CN\&view=chart. Accessed 24 May 2020

World Development Index. https://data.worldbank.org/indicator/NY.GDP.MKTP.KD.ZG?end=2017\& locations $=$ CN-JP-US-EU\&start=1998. Accessed 24 May 2020

World Intellectual Property Indicators, 2017. WIPO. http://www.wipo.int/publications/en/details.jsp?id= 4234. Accessed 24 May 2020

Xing Y (2014) Measuring value added in the People's Republic of China's exports: a direct approach. ADBI Working Paper 493. Asian Development Bank Institute, Tokyo. https:/www.adb.org/sites/ default/files/publication/156348/adbi-wp493.pdf. Accessed 24 May 2020

Yu PK (2004) The sweet and sour story of Chinese intellectual property rights. Paper commissioned for the ESRC Research Seminar Series on "Intellectual property rights, economic development and social welfare: what does history tell us", Queen Mary Intellectual Property Research Institute, University of London, 1 Oct 2004. http://www.peteryu.com/sweetsour.pdf. Accessed 24 May 2020

Publisher's Note Springer Nature remains neutral with regard to jurisdictional claims in published maps and institutional affiliations. 